\title{
Peace, Health, and Sustainable Development in the Middle East
}

\author{
Amirhossein Takian, PhD ${ }^{1,2,3^{*}}$; Golnaz Rajaeieh, $\mathrm{MSc}^{4}$ \\ ${ }^{1}$ Department of Health Management and Economics, School of Public Health, Tehran University of Medical Sciences, Tehran, Iran \\ ${ }^{2}$ Department of Global Health and Public Policy, School of Public Health, Tehran University of Medical Sciences, Tehran, Iran \\ ${ }^{3}$ Health Equity Research Centre (HERC), Tehran University of Medical Sciences, Tehran, Iran \\ ${ }^{4}$ Department of Community Nutrition, National Nutrition and Food Technology Research Institute, Shahid Beheshti University of Medical \\ Sciences, Tehran, Iran
}

\begin{abstract}
Background: As two essential human rights, as well as pillars of sustainable development, health and peace are closely interrelated. Further, health and well-being are the focus of Sustainable Development Goal (SDG) 3, while peace lies at the heart of SDG 16. This paper investigates the relationship between the three concepts of health, peace and sustainable development in the relevant literature.

Methods: This is a qualitative study. Following the establishment of the construct of peace and health through consultation with three key informants (one health sociologists, one high-ranking diplomat, and one health policy maker), we conducted a scoping review of the literature, followed by purposefully obtained grey literature, i.e. UN and country reports. As a result, 30 documents, including journal articles, were identified. We used content analysis to extract themes and categorize them in line with the relevant SDGs.

Results: Lack of peace has direct and indirect impact on health, as well as health workers, the civil society, and the whole community who have in turn a critical role in creating peace. Strong and resilient health systems are essential in reaching out to citizens during war, while achieving SDGs would be impossible if SDG 16 is compromised. Health and peace are interchangeable, and achieving either is impossible without the other.

Conclusion: Physicians and other human resources for health are the key actors in peaceful environment to attain health for all. In the absence of peace, the resilience of health system will be threatened and the hope for sustainable development may fade. Keywords: Health, Middle East, Peace, Sustainable development

Cite this article as: Takian A, Rajaeieh G. Peace, health, and sustainable development in the Middle East. Arch Iran Med. 2020;23(4 suppl 1):S23-S26. doi:10.34172/aim.2020.s5.
\end{abstract}

Received: February 25, 2019, Accepted: October 12, 2019, ePublished: April 1, 2020

\section{Introduction}

The World Health Organization (WHO) constitution (1946) considers the utmost degree of achievable health standard as an essential right of all humankind. ${ }^{1}$ Approaches to health that are based on human-right require more emphasis by policy makers on the needs of vulnerable and those left behind, so-called "equity". Such an approach has been also endorsed by the United Nations' (UN) Sustainable Development Goals (SDGs), particularly SDG 3.8 on universal health coverage (UHC). ${ }^{2,3}$ SDGs explicitly recognize the fundamental mutual relationship between peace and SDGs, none of which can be attained without the other.

SDG 16 is to "promote peaceful and inclusive societies for sustainable development, provide access to justice for all and build effective, accountable and inclusive institutions at all levels". ${ }^{4}$ While this goal mentions peace more explicitly, peace is essential to achieving the SDGs as a whole. There are many targets and indicators under other goals that are closely related to the aim of sustainable peace, ${ }^{4}$ which is an embedded prerequisite of "sustainable development", 5 wich in turn focuses on root causes to build societal resilience. ${ }^{6}$

Peace is not simply the absence of violence. There are various types of peace, which reflect a broader spectrum of the quality of peace. A ceasefire can create peace even if it is temporary, as happened with the Syrian ceasefire in December 2016. ${ }^{7}$ Peace can be defined as freedom from civil disturbance, a state of security, or order within a community provided by law or customs, harmony in personal relations, or a state or period of reciprocal accord between governments. ${ }^{8}$ Theoretically, there are two aspects to peace: 'positive peace' and 'negative peace'. 'While negative peace is the absence of visible and direct violence, which may refer to quality of peace, ${ }^{6}$ positive peace is selfsustaining and is therefore emancipatory in nature. ${ }^{6}$

As two dimensions of essential human right, which have been endorsed by the constitution of many countries, 
health and peace are intrinsically interconnected. ${ }^{8}$ Currently, and in the era of SDGs, peace is considered as a prerequisite of quality public health and a resilient health system. ${ }^{10}$ Considering the definition of health by the WHO as complete state of mental, physical, social and spiritual health, health is not attainable without peace. Countries in conflict need to prioritize building resilient health systems for delivering productive healthcare. ${ }^{11,12}$

The relationship between health, sustainable development and peace has not been substantially studied. This study investigates this relationship and brings some examples from conflicting countries in the Middle East. We aim to draw practical lessons to show how peace can contribute to a resilient health and a healthier society.

\section{Materials and Methods}

Our initial search identified a total of 1351 articles. We removed 189 duplicates; as a result, 1162 articles plus grey literature remained. We screened the titles and abstracts for relevancy and further duplication. Finally, 30 articles were included for more detailed analysis.

We included studies that mentioned resilient health system during war, the interaction between heath and peace, health system implication during war and the relationship between peace, health and sustainable development.

We reviewed all remaining articles and summarized their information. Both authors held regular meetings over a period of two months to discuss findings and reach consensus about the categorization of findings.

\section{Results}

The impact of war on health is fundamental, and it can ultimately influence the achievement of SDGs. ${ }^{8}$ Health often means survival from war and its consequences, which is in turn associated with access to essential life needs, i.e. water, food, healthcare, and many public health outcomes. ${ }^{8}$ As an example, armed conflict is recognized as one of the biggest threats to human societies, which affects health in both direct and indirect ways. ${ }^{13}$ As a major cause of disease epidemics, such conflicts, e.g. war, are associated with death and injury, reduced or abolished access to healthcare services, increasing incidence of communicable diseases, reduced access to sanitary water, psychosocial effects, and malnutrition. ${ }^{13}$ Similar to its direct impact, indirect consequences of war can be serious in terms of increased mortality and endangering public health.

We found nine mechanisms, through which the lack of peace may affect health and achieving sustainable development (Table 1).

Health system strengthening towards building a resilient health system is crucial in reducing the impact of conflict on health and withstanding shocks. ${ }^{18}$ During any crisis, resilient health systems must have robust tailored plans to enhance the capacity of health actors, e.g. relevant institutions, to prepare and assist people for effective response.

As described in Table 1, the relationship between peace and health is intrinsically mutual. The role of doctors and other healthcare practitioners is crucial in protecting population health. Indeed, peace is the most significant factor to achieve health for all. In addition, health is innocent enough to play a brokerage role by bringing the conflicting parties to discuss mutually beneficial interventions for all parties involved. ${ }^{13}$ Moreover, healthcare staff have a great responsibility to maintain humanitarian interventions and public health during and after armed conflicts, within the context of resilient health systems. ${ }^{21}$ This requires to keep channels of humanitarian assistance open, including cross-border assistance, and balancing the control between the government and other parties in action. ${ }^{22}$ In the area of health, many humanitarian agencies are responsible to protect and help the victims of war, either through direct actions on behalf of the victims, or providing them with food, shelter, water, vaccinations and medico-surgical care.

\section{Discussion}

Peace, health and sustainable development are interlinked. Health is at the heart of SDGs, while achieving sustainable development would be impossible if peace were to be compromised. Peace is not simply the absence of violence. Nonetheless, war, as one of the most prominent examples of lack of peace, has direct and indirect health consequences, ${ }^{23}$ i.e. disrupted power supply and water sanitation, reduced immunizations, maternal and child health difficulties, psychosocial consequences, and physical deprivations. ${ }^{24}$

Health is a right for all. ${ }^{25}$ Hence, hospitals, medical units and health care personnel require special protection during crisis to maintain health promotion, disease control and prevention, treatment of acute illnesses and chronic care, and appropriate responses to emerging public health threats. ${ }^{26}$ When peace is compromised, health system strengthening is crucial in enhancing health security. Resilient health systems are able to absorb disturbance and adapt and respond to crisis, through integrated approaches for provision of needed services before or during a disaster. ${ }^{27}$ Indeed, a resilient health system should be able to regulate itself.

Reciprocally, health can also affect peace. For instance, healthcare personnel are trained to utilize primary, secondary and tertiary prevention strategies to reduce the adverse effects of war on health. ${ }^{20}$ Even when severe conflict is in place, healthcare staff are expected to resume their duties in development and implementation of relevant interventions to promote public health, to ensure that the essential healthcare services are available and healthy and safe physical environments are maintained. These require effective advocacy for human, financial, and other resources that are needed to implement essential and emergency healthcare programs, ${ }^{8}$ which may nevertheless 
Table 1. Consequences of Lack of Peace on Health and Sustainable Development

\begin{tabular}{|c|c|c|}
\hline Consequences of Lack of Peace & $\begin{array}{l}\text { Direct or } \\
\text { Indirect Impact } \\
\text { on Health }\end{array}$ & Example \\
\hline 1. Injury, illness, disability, and death & Direct & $\begin{array}{l}\text { During the period of March 2003-July 2006, } 654965 \text { people were killed in } \\
\text { Iraq war, most of them because of gunfire. }{ }^{11} \\
\text { From late } 2001 \text { until 2014, more than } 26,270 \text { citizens were killed in } \\
\text { Afghanistan. }{ }^{13}\end{array}$ \\
\hline $\begin{array}{l}\text { 2. Long-term physical or psychological effects on the } \\
\text { individuals injured during war }\end{array}$ & Indirect & $\begin{array}{l}\text { The current situation in Afghanistan may be related to an additional } 200000 \\
\text { indirect deaths. }{ }^{13}\end{array}$ \\
\hline $\begin{array}{l}\text { 3. Conflict damages the social construction of the society } \\
\text { and disrupts all activities of normal life }\end{array}$ & Indirect & $\begin{array}{l}\text { Extensive increase in the number of casualties during the post-war era in } \\
\text { Afghanistan due to military and police injuries. }{ }^{14}\end{array}$ \\
\hline $\begin{array}{l}\text { 4. Destruction of healthcare infrastructure, e.g. clinics and } \\
\text { hospitals, most of which will not be completely restored for } \\
\text { months or years to come. }\end{array}$ & Indirect & $\begin{array}{l}\text { Severe decrease in pharmaceutical production in Syria, which was } 90 \% \\
\text { before the war in Syria and reduced to } 10 \% \text {, resulting in a significant shortage } \\
\text { of drugs and essential medicines across the country. }{ }^{15}\end{array}$ \\
\hline $\begin{array}{l}\text { 5. Displacing people as refugees in other countries, or } \\
\text { internally displaced people within their own countries. }\end{array}$ & Indirect & $\begin{array}{l}\text { Every minute, nearly } 20 \text { people are displaced as a result of war and conflict. } \\
\text { In } 2016 \text {, the total number of displaced people reached } 65.6 \text { million globally, } \\
\text { plus over } 10 \text { million stateless people around the globe who are denied a } \\
\text { nationality. }{ }^{16}\end{array}$ \\
\hline $\begin{array}{l}\text { 6. Harming the environment through reduction of non- } \\
\text { renewable natural resources and contaminating the } \\
\text { environment with harmful materials. }\end{array}$ & Indirect & $\begin{array}{l}\text { In our region, wars and other conflicts in our neighboring countries, e.g. } \\
\text { Iraq and Afghanistan, have drastically affected natural resources in Iran. } \\
\text { High consumption of petroleum-based fuels, military vehicles that produce } \\
\text { hundreds of thousands of tons of } \mathrm{CO}_{2^{\prime}} \text { carbon monoxide, nitrogen oxides, } \\
\text { hydrocarbons, and sulfur dioxide at an extremely high rate within the war } \\
\text { areas. }^{17}\end{array}$ \\
\hline $\begin{array}{l}\text { 7. Draining financial, human, and other resources away } \\
\text { from more productive operations, such as healthcare } \\
\text { provision. }\end{array}$ & Indirect & $\begin{array}{l}\text { In } 2005 \text {, worldwide military budget passed US } \$ 1.1 \text { trillion, which is equal } \\
\text { to } 2.5 \% \text { of global GDP, or an average spending of } \$ 173 \text { per capita. Only in } \\
\text { the United States, the Center for Disease Control and Prevention on terrorism } \\
\text { preparedness spent } \$ 1.6 \text { billion in } 2006 \text {, which was } 19 \% \text { of the CDC's total } \\
\text { yearly budget. }{ }^{18}\end{array}$ \\
\hline $\begin{array}{l}\text { 8. Expansion of violence culture and habits across the } \\
\text { society, where most conflicts are sought to be resolved } \\
\text { through brutal means. }{ }^{2}\end{array}$ & Indirect & $\begin{array}{l}\text { Many cultural heritage and art pieces were stolen during the war and } \\
\text { occupation in Iraq, i.e. the national library and the national museum, as well } \\
\text { as a number of important cultural monuments that were massively damaged } \\
\text { and looted during the period of the occupation. }{ }^{19}\end{array}$ \\
\hline $\begin{array}{l}\text { 9. Risk for the spread of infectious diseases, while the } \\
\text { private sector that is mostly concentrated in urban settings } \\
\text { is not capable of tackling the problem even by the use of } \\
\text { advanced care services. }{ }^{.0}\end{array}$ & Indirect & $\begin{array}{l}\text { In Yemen, war has had devastating impact on mother and child health. } \\
\text { Vaccination rates have decreased, the incidence of diarrheal diseases has } \\
\text { increased among children, malnutrition has increased among mothers and } \\
\text { children, while both maternal and U5MR have increased. } .^{20}\end{array}$ \\
\hline
\end{tabular}

face several constraints, i.e. poor security, both for the victims and staff that in turn could slow down the relief operations and very often limit their effectiveness. ${ }^{28}$ The role of civil society is fundamental in bringing health concerns to the center of foreign policy, so that effective approaches can be taken to address such challenges. ${ }^{29}$

As a bridge for peace (HBP), health is a multidimensional policy and planning framework to support health workers in delivering health programmers within war and postconflict situations. Indeed, health can also simultaneously contribute to peace-building. ${ }^{30} \mathrm{HBP}$ entails a meaningful collaboration among organizations, institutions, and individuals from various backgrounds. This approach is crucial in tackling two fundamental and catastrophic problems during conflict, which have direct and indirect consequences on health: blocking of sufficient humanitarian assistance and direct intentional attacks on the health care system as a weapon of war. ${ }^{30}$

In conclusion, health and peace are interchangeable; achieving either is impossible without the other. Health is fundamental to sustainable development, which is also impossible to achieve without meaningful and widespread peace. As such, peace and justice, i.e. strong institutions are defined as SDG16, without which other SDGs are unattainable. Strengthening health systems towards building a resilient health system, especially in countries that are at risk of war, is crucial in decreasing the effects of lack of peace on health. Strengthening the civil society, i.e. health-related NGOs, to help people and provide basic care during war, while placing health and humanitarian issues at the heart of foreign policy, are fundamental to planning of all countries, particularly in the Middle East, in galvanizing their path towards sustainable development.

\section{Authors' Contribution}

AT conceived the study. GR conducted data collection with AT contributing to analysis and interpretation of findings. Both authors approved the final draft of manuscript. AT is guarantor.

\section{Conflict of Interest Disclosures}

None.

\section{Ethical Statement}

Not applicable. 


\section{References}

1. World Health Organization (WHO). Human Rights and Health. Available from: http://www.who.int/news-room/factsheets/detail/human-rights-and-health.2017.

2. Transforming our World: The 2030 Agenda for Sustainable Development. UN General Assembly. Available from: https:// www.un.org/en/development/desa/population/migration/ generalassembly/docs/globalcompact/A_RES_70_1_E.pdf.

3. IS Global Barcelona Institute for Global Health? The Sustainable Development Goals (SDGs) and Global Health. Available from: https://www.isglobal.org/en/-/global-healthinequities.

4. Nehlsen I, Pascal R. Lens on the sustainable development goals. GPPAC; June 2017. Available from: https://www.gppac. net/files/2018-11/A\%20Peacebuilding\%20Lens\%20on\%20 the $\% 20$ Sustainable $\% 20$ Development $\% 20$ Goals_public $\% 20$ background\%20paper.pdf.

5. The SDGs and Prevention for Sustaining Peace: Exploring the Transformative Potential of the Goal on Gender Equality. International Peace Institute: Vienna; 2016. Available from: https://www.ipinst.org/wp-content/uploads/2016/11/1611_ SDGs-and-Prevention.pdf.

6. Caparini M, Milate G. Sustaining Peace and Sustainable Development in Dangerous Places. Swedish SIPRI (Stockholm International Peace Research Institute) Yearbook; 2017. Armament, Disarmament and International Security. Avaialble from: https://www.sipriyearbook.org/.

7. Paris R. Human Security: Paradigm shift or hot air? International Security. 2001;26(2):87-102

8. Levy BS. Health and Peace. Croat Med J. 2002; 43(2):114-6.

9. Ghobarah HA, Huth P, Russett B. The post-war public health effects of civil conflict. Soc Sci Med. 2004;59(4):869-84. doi: 10.1016/j.socscimed.2003.11.043

10. Institute of Medicine. The Future of Public Health. Washington (DC): National Academy of Sciences; 1988.

11. Conor C, Rajkotia Y, Lin Y, Figueiredo P. Angola Health System Assessment. Bethesda: PHR Plus; 2005

12. Arie S. Polio outbreak leads to calls for a "vaccination ceasefire" in Syria. BMJ. 2013;347:f6682. doi: 10.1136/bmj. f6682.

13. World Health Organization (WHO). Humanitarian Health Action. Available from: http://www.who.int/hac/ techguidance/ hbp/about_why/en/.

14. Crawford NC. War-related Death, Injury, and Displacement in Afghanistan and Pakistan 2001-2014. Watson institute for international studies; 2015. Available form: https:// watson.brown.edu/costsofwar/files/cow/imce/papers/2015/ War\%20Related\%20Casualties\%20Afghanistan\%20and\%20 Pakistan\%202001-2014\%20FIN.pdf.

15. Taleb ZB, Bahelah R, Fouad FM, Coutts A, Wilcox M, Maziak W. Syria: health in a country undergoing tragic transition. Int J Public Health. 2015;60(Suppl 1):S63-72. doi: 10.1007/ s00038-014-0586-2.

16. Bcheraoui $\mathrm{CH}$, Jumaan $\mathrm{A}$, Collison $\mathrm{M}$, Daoud F, Mokdad A.
Health in Yemen: losing ground in war time. Global Health. 2018;14(1):42. doi: 10.1186/s12992-018-0354-9.

17. Watson institute International and Public Affairs. Cost of war. Environmental costs. Available from: https://watson. brown.edu/costsofwar/costs/social/environment. Accessed November 2018).

18. Health System Global (HSG). Building health systems resilience in fragile States emerging from conflict or other forms of severe disruption. Report of a session organized by the Thematic Working Group on Health Systems in Fragile and Conflict Affected States. 4th Global Symposium on Health Systems Research 16 November 2016. Available from: https:// healthsystemsglobal.org/upload/resource/FCAS_TWG_panel_ complete_slide_set_16Nov16.pdf.

19. Global Policy Forum. Consequences of the war and occupation of Iraq. Available from: https://www.globalpolicy. org/humanitarian-issues-in-iraq/consequences-of-the-warand-occupation-of-iraq.html.

20. Sharara SL, Kanj SS. War and Infectious Diseases: Challenges of the Syrian Civil War. PLoS Pathog. 2014;10(10):e1004438. doi: 10.1371/journal.ppat.1004438.

21. Ugalde A, Selva-Sutter E, Castillo C, Paz C, Cañas S. The health costs of war: can they be measured? Lessons from El Salvador. BMJ. 2000;321(7254):169-72. doi: 10.1136/ bmj.321.7254.169.

22. Medecins Sans Frontieres. An Open letter to the Member States of the High Level Group on Syria. Available from: https://www.doctorswithoutborders.org/what-we-do/newsstories/news/letter-member-states-high-level-group-syria.

23. Sustainable Development Goals. What is Sustainable Development? Available from: https://www.un.org/ sustainabledevelopment/blog/2015/09/what-is-sustainabledevelopment/.

24. Birch M, Cave B, Elmi F, Karpf B. Predicting the unthinkable: health impact assessment and violent conflict. Med Confl Surviv. 2014;30(2):81-90. doi: 10.1080/13623699.2014.896174

25. Benjamin D. War and Public Health. Health Generetion. 2007; 7(3):1-3. Available from: http://www.epi.umn.edu/mch/ wp-content/uploads/2015/09/hg_april07.pdf.

26. Takian A, Raoofi A, Kazempour-Ardebili S. COVID-19 battle during the toughest sanctions against Iran. Lancet. March 17, 2020. doi: 10.1016/ S0140-6736(20)30668-1.

27. Cahill KM. Health and foreign policy: an American view. Ann Trop Med Parasitol. 1997;91(7):735-41. doi: 10.1080/00034989760473

28. Perrin P. A Handbook on War and public Health. Geneva: International Committee of the Red Cross: 1996

29. WHO. Health and sustainable developments. Key Health Trends. Available from: http://apps.who.int/iris/ handle/10665/68755

30. Medecins sans Frontieres. Syria: Urgent need for cross border aid for Syrians. Available from: https://www. doctorswithoutborders.org/what-we-do/news-stories/news/ syria-urgent-need-cross-border-aid-syrians. 